\title{
Association between High Serum Homocystine and Preeclampsia
}

\author{
Ferdausi $\mathrm{M}^{1}$, Khatun $\mathrm{M}^{2}$, Yusuf $\mathrm{MA}^{3}$, Rahman $\mathrm{A}^{4}$, Rahman $\mathrm{Z}^{5}$
}

\begin{abstract}
Background: Hyperhomocysteinemia is an important biological marker for adverse outcome of pregnancy. Objective: The aim of the present study was to see the association of high serum homocysteine with preeclampsia (PE). Methodology: This cross sectional study was carried out in the Department of Obstetrics and Gynaecology at Sir Salimullah Medical College \& Mitford Hospital, Dhaka. All pregnant women with or without eclampsia admitted at the hospital were included in this study. Pregnant women with diabetes mellitus, chronic hypertension, multiple pregnancies, chronic renal disease and patients taking anti-folate drugs were excluded from this study. Fasting serum total homocysteine (tHomocysteine) concentration was estimated by Fluorescence Polarization Immunoassay (FPIA) method. Result: A total number of 50 PE patient [Severe PE (23) \& Mild PE (27)] and 50 pregnant women without PE were selected purposively. Fasting serum total homocysteine (tHomocysteine) concentration was estimated by fluorescence polarization immunoassay (FPIA) method. Mean serum homocysteine concentration in severe PE, mild PE and pregnant women without PE were $11.54 .58 \mathrm{~mol} / \mathrm{L}, 10.435 .12$ and 5.701 .30 respectively. Serum homocysteine was significantly increased in severe PE and mild PE in comparison to without PE group. Howere severe PE and mild PE group cases did not differ with respect to serum homocysteine. Conclusion: Significant positive correlation was found between serum homocysteine concentration and urinary total protein, uric acid level, systolic blood pressure and diastolic blood pressure. [J Shaheed Suhrawardy Med Coll, 2013;5(1):21-25]
\end{abstract}

Key words: Homocysteine, preeclampsia, eclampsia, pregnancy

Received: December 2012; Revised: March 2013; Accepted: May 2013

\section{Introduction}

Preeclampsia is a pregnancy-specific condition that increases maternal and perinatal mortality and morbidity ${ }^{1}$. If preeclampsia is not diagnosed or treated, it can progress to maternal multiorgan failure, coagulopathy and maternal and fetal death in severe form ${ }^{1}$. It is widely accepted that preeclampsia starts with poor placental perfusion associated with defective trophoblast invasion ${ }^{2}$; however this is not sufficient to explain the disease. Widely accepted concept for the development of preeclampsia is the interaction of reduced placental perfusion with maternal factors ${ }^{2}$.

Elevated circulating homocysteine is a risk factor for endothelial dysfunction and vascular disease such as atherosclerosis and occlusive vascular disorders ${ }^{3}$. It is sulfur containing essential amino acid required for the growth of cells and tissues in the human body. It is hypothesized that hyperhomocysteinemia might damage the vascular endothelium of the developing placenta by promoting oxidative stress, thereby increasing contractile response and the production of pro-coagulants and vasoconstrictor ${ }^{4}$. Plasma homocysteine is normally lower throughout pregnancy than in the non-pregnant state ${ }^{5}$. Homocysteine concentrations are directly correlated with albumin concentration, which decrease during pregnancy and decrease further in pregnant women taking folic acid supplements. Vollset et $\mathrm{al}^{6}$ reported that hyperhomocysteinemia may also be an important biological marker for adverse outcome of pregnancy and even possibly a cause of or a contributor to the complications of pregnancy. An increased risk of preeclampsia, premature

1. Dr. Munira Ferdausi, Associate Professor, Department of Obstetrics and Gynaecology, Shaheed Suhrawardy Medical College \& Hospital, Dhaka

2. Prof. Mahmuda Khatun, Professor, Department of Obstetrics \& Gynaecology, Sir Salimullah Medical \& Mitford Hospital, Dhaka

3. Dr. Md. Abdullah Yusuf, Lecturer, Department of Microbiology, Shaheed Suhrawardy Medical College, Dhaka

4. Dr. Aurin Rahman, Medical officer, American Super Speciality Hospital, Dhaka

5. Zara Rahman, Bioelectrical Engineering, Hofstra University, New York, USA

\section{Correspondence}

Dr. Munira Ferdausi, Associate Professor Department of Obstetrics and Gynaecology, Shaheed Suhrawardy Medical College \& Hospital, Sher-E-Bangla Nagar, Dhaka, Bangladesh; E mail: onlymunira@yahoo.com; Cell No.: +8801711467267

Conflict of interest: Not declared

Financial Support: None

Contributions by authors: Dr. M. Ferdausi contributed from preparation of protocol to write up of the article. Prof. M. Khatun, Dr. A. Rahman \&

Z .Rahman have corrected the article. Dr. M. A. Yusuf has done the statistical work. 
delivery, very low birth weight, neural tube defects and clubfoot occurs in those women who are suffering from hyperhomocysteinemia ${ }^{6}$.

Studies regarding homocysteine in Bangladesh are very rare. Two cross-sectional studies conducted by Zaher et $\mathrm{al}^{7}$ and $\mathrm{Banu}^{8}$ found positive association between homocysteine with all forms of coronary heart disease. Wahab ${ }^{9}$ showed that folic acid supplementation decreased fasting serum homocysteine concentration in coronary heart disease patients. Hyperhomocysteinemia is treatable by supplementation of vitamins like vitamin B6, B12 and folic acid. So, if hyperhomocysteinemia is detected in early pregnancy, homocysteine level can be decreased to normal value by vitamin supplementation and thus the occurrence of preeclampsia can be prevented in the population of this country.

Therefore, the present study was designed to see the association of elevated plasma homocysteine level with preeclampsia and especial attention can be given to this group of women during antenatal care for prevention of the pregnancy adverse outcomes.

\section{Methodology}

This cross-sectional study was conducted in the Department of Gynaecology and Obstetrics at Sir Sallimullah Medical College (SSMC) and Mitford Hospital (MH), Dhaka, Bangladesh from July 2004 to June 2006 for a period of two (2) years. All pregnant women with or without eclampsia admitted at the hospital were included in this study. Women with preeclampsia were divided into two groups named as mild and moderate preeclampsia. Mild pre-eclampsia was diagnosed by BP with $>140 / 90 \mathrm{~mm}$ of $\mathrm{Hg}$ or $<160 / 110 \mathrm{~mm}$ of $\mathrm{Hg}$ and proteinuria with $>0.3 \mathrm{gm} / 24$ hours urine. Severe pre-eclampsia was diagnosed by BP $>160 / 110 \mathrm{~mm}$ of $\mathrm{Hg}$ and proteinuria with $>2$ gm/24 hours urine. Pregnant women without preeclampsia or any other uncomplicated pregnancies who were attending an outpatient department and or inpatient department of the study place were also selected. Pregnant women with diabetes mellitus, chronic hypertension, multiple pregnancies, chronic renal disease and patients taking anti-folate drugs were excluded from this study. Fasting serum total homocysteine (tHomocysteine) concentration was estimated by Fluorescence Polarization Immunoassay (FPIA) method. The reading was taken by the 'AxSYM system' (Abbott, USA) auto-analyzer. Urinary total protein, fasting blood sugar and serum creatinine were measured accordingly. Computer based statistical analysis were carried out with appropriate techniques and systems. All data were recorded systematically in preformed data collection form (questionnaire) and quantitative data were expressed as mean and standard deviation and qualitative data were expressed as frequency distribution and percentage. Statistical analysis was performed by using window based computer software devised with Statistical Packages for
Social Sciences (SPSS 17.0) (SPSS Inc, Chicago, IL, USA). $95 \%$ confidence limit was taken. Probability value $<0.05$ was considered as level of significance. The association between qualitative variables was measured by Chi-Square test. Student's t test has been performed to see the association between quantitative variables. Serum homocysteine concentration among severe PE, mild PE and without PE women was compared by ANOVA. The summarized data was interpreted accordingly and was then presented in the form of tables.

\section{Results}

A total number of 100 pregnant women were enrolled in this study of which 50 pregnant women were with preeclampsia and 50 pregnant women were normotensive. The mean age of the different study groups did not show any significant differences (without PE 25.84 \pm 5.43 , mild PE 24.00 \pm 4.14 and severe PE $25.83 \pm 5.69 ; \mathrm{p}=\mathrm{ns}$ ). Mean height of different study groups showed significant differences (mild $\mathrm{PE}=158.4 \pm 2.7$ $\mathrm{cm}$, severe PE $156.2 \pm 3.4 \mathrm{~cm}$ and without PE $156.4 \pm 2.8 \mathrm{~cm}$; $\mathrm{p}=0.01)$. Women with more mean weight was found to suffer from more in PE than the lighter group (mild PE $61.1 \pm 4.5 \mathrm{~kg}$, severe PE 5.98 $\pm 6.5 \mathrm{~kg}$ and without PE $53.3 \pm 4.7 \mathrm{~kg}$; $\mathrm{p}<0.001)$. There were significant differences of BMI $(p<0.001)$ between these groups. The mean BMI $\mathrm{kg} / \mathrm{m}^{2}$ of the different study groups were $21.7 \pm 1.7$ in without PE women, $24.3 \pm 1.2$ in mild $\mathrm{PE}$ and $24.6 \pm 2.3$ in severe PE. Gestational age showed significant difference $(\mathrm{p}=0.02)$. Mean gestational age in the without PE group was $30.8 \pm 4.03$ week, severe PE $31.7 \pm 3.59$ week and mild PE $28.7 \pm 4.05$ week. Mean systolic blood pressure in the different study groups were $108.2 \pm 08.73 \mathrm{~mm}$ of $\mathrm{Hg}$ in without $\mathrm{PE}$ women, $163.9 \pm 11.1 \mathrm{~mm}$ of $\mathrm{Hg}$ in severe PE and $139.6 \pm 7.06 \mathrm{~mm}$ of $\mathrm{Hg}$ in mild group. Significant difference was found in this variable $(p<0.001)$. Mean diastolic blood pressure $(\mathrm{mm}$ of $\mathrm{Hg}$ ) in the women without $\mathrm{PE}$ group was $67.7 \pm 7.09 \mathrm{~mm}(\mathrm{Hg})$, mild PE $96.3 \pm 5.5 \mathrm{~mm}(\mathrm{Hg})$ and in severe PE $113.4 \pm 84.87 \mathrm{~mm}(\mathrm{Hg})$. This variable also showed significant difference between the study groups $(\mathrm{p}<0.001)$. Significant differences were found between total platelet count and different types of study population $(p<0.001)$, between total urinary protein and different types of study population $(\mathrm{p}<0.001)$. No significant differences were found between fasting blood sugar, uric acid, serum creatinine among different groups of study population. Mean $\mathrm{Hb}$ concentration in different study groups showed no significant differences $(\mathrm{p}=\mathrm{NS})$. Mean $\mathrm{Hb}$ concentration in between mild $\mathrm{PE}$ and severe PE were more or less same than the control group (Table 1).

The mean SD of serum homocysteine concentration was $11.5 \pm 4.58 \mathrm{~mol} / \mathrm{L}$ in severe PE, $10.43 \pm 5.12 \mathrm{~mol} / \mathrm{L}$ in mild PE and $5.70 \pm 1.37 \mathrm{~mol} / \mathrm{L}$ in without $\mathrm{PE}$ group. There were significant differences between different groups of study population. Serum homocysteine concentration among study subjects were compared by ANOVA which showed significant difference $(p<0.001)$ among severe PE, mild PE and without PE group. 
Table 1: General Characteristics of the study groups

\begin{tabular}{|c|c|c|c|c|}
\hline Variables & $\begin{array}{r}\text { Mild PE } \\
\text { Mean } \pm \text { SD } \\
(n=23)\end{array}$ & $\begin{array}{r}\text { Severe PE } \\
\text { Mean } \pm \text { SD } \\
(n=27)\end{array}$ & $\begin{array}{r}\text { Without PE } \\
\text { Mean } \pm \text { SD } \\
(n=50)\end{array}$ & $p$ value \\
\hline Maternal age(years) & $24.00 \pm 4.14$ & $25.83 \pm 5.69$ & $25.84 \pm 5.43$ & NS \\
\hline Height $(\mathrm{cm})$ & $158.4 \pm 2.7$ & $156.2 \pm 3.4$ & $156.4 \pm 2.8$ & 0.01 \\
\hline Weight (kg) & $61.1 \pm 4.5$ & $59.8 \pm 6.5$ & $53.3 \pm 4.7$ & $<0.001$ \\
\hline $\mathbf{B M I}\left(\mathrm{kg} / \mathrm{m}^{2}\right)$ & $24.3 \pm 1.2$ & $24.6 \pm 2.3$ & $21.7 \pm 1.7$ & $<0.001$ \\
\hline Monthly income(taka) & $6611 \pm 2450$ & $7636 \pm 4445$ & $10560 \pm 4768$ & $<0.001$ \\
\hline Gestational age(months) & $28.7 \pm 4.05$ & $31.7 \pm 3.59$ & $30.8 \pm 4.03$ & 0.02 \\
\hline Systolic BP(mmHg) & $139.6 \pm 7.06$ & $163.9 \pm 11.1$ & $108.2 \pm 8.73$ & $<0.001$ \\
\hline Diastolic BP(mmHg) & $96.3 \pm 5.5$ & $113.48 \pm 4.87$ & $67.7 \pm 7.09$ & $<0.001$ \\
\hline Haemoglobin (g/dl) & $10.7 \pm 0.56$ & $10.6 \pm 0.54$ & $10.4 \pm 0.73$ & NS \\
\hline Platelets $\left(1000 / \mathrm{mm}^{3}\right)$ & $187.5 \pm 37.4$ & $167.6 \pm 36.24$ & $206.0 \pm 32.2$ & $<0.001$ \\
\hline Serum creatinine $(\mathrm{mg} / \mathrm{dl})$ & $1.38 \pm 1.33$ & $1.21 \pm 0.17$ & $1.06 \pm 1.01$ & NS \\
\hline $\mathbf{F B S}(\mathrm{mmol} / \mathrm{l})$ & $5.67 \pm 0.82$ & $5.82 \pm 1.1$ & $5.32 \pm 0.76$ & NS \\
\hline Serum uric $\operatorname{acid}(\mathrm{mg} / \mathrm{dl})$ & $5.87 \pm 2.01$ & $6.13 \pm 1.17$ & $3.7 \pm 0.42$ & $<0.001$ \\
\hline UTP (g/24 hour) & $0.57 \pm 1.26$ & $4.68 \pm 2.81$ & $0.09 \pm 0.06$ & $<0.001$ \\
\hline
\end{tabular}

* $\mathrm{BP}=$ Blood pressure; $\mathrm{UTP}=$ Urinary total protein; ANOVA was done to see the association; $* \mathrm{p}$ value $<0.05$ was taken as significant.

Table 2: Comparison of Serum Homocysteine level among Study groups

\begin{tabular}{lll}
\hline Study Groups & $\begin{array}{l}\text { Hcy }(\mathrm{mol} / \mathrm{L}) \\
(\text { Mean } \pm \mathrm{SD})\end{array}$ & p value \\
\hline Mild PE & $10.43 \pm 5.12$ & \\
Severe PE & $11.5 \pm 4.58$ & $<0.001$ \\
Without PE & $5.70 \pm 1.37$ & \\
\hline
\end{tabular}

* ANOVA was done to see the association

$*$ Hcy $=$ Homocysteine

Positive correlation was noticed $(\mathrm{r}=0.472$; $\mathrm{p}<0.001)$ between serum homocysteine and BMI; between serum homocysteine and urinary total protein $(\mathrm{r}=0.278 ; \mathrm{p}=0.005)$; between serum homocysteine and uric acid level $(\mathrm{r}=0.478 ; \mathrm{p}=0.001)$; between serum homocysteine and platelet count $(\mathrm{r}=0.326 ; \mathrm{p}=0.001)$; between serum homocysteine and systolic blood pressure $(\mathrm{r}=0.528 ; \mathrm{p}=<0.001)$ and between serum homocysteine and diastolic blood pressure $(\mathrm{r}=0.579 ; \mathrm{p}=<0.001)$ (Table 3$)$.

Table 3: Correlation of Serum Homocysteine with Biochemical Parameters

\begin{tabular}{lcc}
\hline Variables & r & p value \\
\hline UTP $(\mathrm{gm} / 24 \mathrm{hr}$ urine) & 0.278 & 0.005 \\
Uric Acid $(\mathrm{mg} / \mathrm{dl})$ & 0.478 & $<0.001$ \\
TPC $\left(\mathrm{X} 1000 / \mathrm{mm}^{3}\right)$ & 0.326 & 0.001 \\
Systolic BP $(\mathrm{mm}$ of $\mathrm{Hg})$ & 0.528 & $<0.001$ \\
Diastolic BP $(\mathrm{mm}$ of $\mathrm{Hg})$ & 0.579 & $<0.001$ \\
\hline
\end{tabular}

* $\mathrm{r}=$ correlation coefficinet; $\mathrm{BP}=\mathrm{Blood}$ pressure $\mathrm{TPC}=$ Total Plate count; $\mathrm{UTP}=$ urinary total protein

\section{Discussion}

An elevated plasma homocysteine level is associated with a variety of vascular disorders; however it is not clear whether the association is causal or an effect of the disease process. A meta-analysis demonstrated a relationship between homocysteine and coronary artery disease, cerebro-vascular disease, and peripheral vascular disease ${ }^{10}$. The risk of coronary artery disease is seen to increase across a range of homocysteine values. Welch et at $^{4}$ suggested that it was a positive association between homocysteine and ischemic heart disease $\&$ showed that increase in homocysteine of 5 $\mathrm{mol} / \mathrm{L}$, the rate of ischemic heart disease risk increased by $84.0 \%$. Similarly this study demonstrated a relationship between increased homocysteine and development of preeclampsia.

In this study it has been measured serum Hcy concentration in 50 diagnosed $\mathrm{PE}$ patients and 50 uncomplicated pregnancies. The mean serum Hcy level found to be significantly high $(\mathrm{P}<0.001)$ in $\mathrm{PE}$ cases compared to non PE group. This finding conforms to other similar studies done by Cotter et $\mathrm{al}^{11}$, Lopez-Quesada et $\mathrm{al}^{12}$, Walker et $\mathrm{a}^{15}$, Refsum et $\mathrm{a}^{13}$, Rajkovic et $\mathrm{al}^{13}$. Currently reported two studies by Mignini et $\mathrm{al}^{14}$ and Ingec et $\mathrm{al}^{15}$ showed serum homocysteine concentration in patients with PE were higher than those with uncomplicated pregnancy which were similar to ths present study. Mean serum homocysteine concentrations in women with severe PE were significantly higher than those in without PE subject $(11.5 \pm 4.58 \mathrm{~mol} / \mathrm{L}$ versus $5.70 \pm 1.37 \mathrm{~mol} / \mathrm{L})$. Similar studies were done by Cotter et $\mathrm{al}^{11}$ and Ingec et $\mathrm{al}^{15}$ and found similar results ${ }^{11-15}$. Mean serum homocysteine concentrations in women with mild PE were significantly higher than those in without PE group $(10.43 \pm 5.12$ versus $5.70 \pm 1.37 \mathrm{~mol} / \mathrm{L})$. These results were consistent with the result of Cotter et $\mathrm{al}^{11}$; however this findings differ from Ingec et $\mathrm{al}^{15}$ who demonstrated that plasma homocysteine is not increased in mild PE. No significant difference was detected in the serum levels of hemoglobin and creatinine among all groups. These findings were similar with the findings of Ingec et $\mathrm{al}^{15}$. Uric acid and proteinuria were higher in PE group than without PE group 
( $<<0.001)$ however, platelet count was lower in cases than without PE group $(p<0.001)$; These findings were consistent with the findings of Ingec et $\mathrm{al}^{15}$.

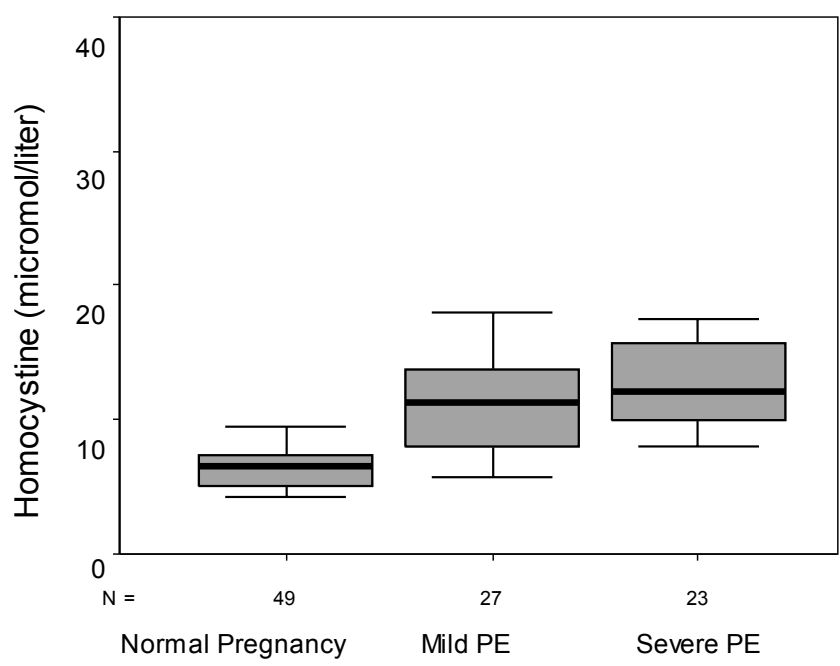

Types of Patients

Figure I: Box Plot of Hcy Concentration among Types of Patients (In the box plot, there are no outliers; the whiskers are not equal which indicates that the data is not normally distributed. Within the box, the midline is not in the centre which indicates that the data is not normal)

In this study, the mean BMI of PE group was higher than without PE group $(\mathrm{p}<0.001)$. When it was measured height and weight between the women with and without $\mathrm{PE}$, there was found a significant difference of weight $(\mathrm{P}<0.001)$.

The study was also revealed significant positive correlation between serum Hcy concentration and proteinuria $(\mathrm{r}=0.278$; $\mathrm{p}=0.0050)$, serum Hcy concentration and uric acid ( $\mathrm{r}$ $=0.478 ; \mathrm{p}<0.001$ ). These findings were similar to Ignec et $\mathrm{al}^{15}$. This study also observed significant negative correlation between serum Hcy concentration and platelet count $(r=0.326 ; p=0.001)$. These findings were consistent with the findings of Ignec et $\mathrm{al}^{15}$. There was also positive correlation between serum Hcy with systolic blood pressure $(\mathrm{r}=0.528 ; \mathrm{p}=<0.001)$ and serum Hcy concentration with diastolic blood pressure $(\mathrm{r}=0.579 ; \mathrm{p}=<0.001)$.

It is known that serum homocysteine level increase with age $^{17}$ and plasma homocysteine level decrease throughout pregnancy ${ }^{18}$; however the study population provided blood samples at a similar gestational age. Women with or without $\mathrm{PE}$ groups were not matched for parity. In this study parity was not associated with the homocysteine level. A possible confounder in any analysis of PE is the presence of different ethnic groups, though in the present study all population was of Asiatic origin. In the present study fasting level of homocysteine was studied. Therefore, this is able to exclude a possible effect of dietary factors on homocysteine values ${ }^{19}$.

It is possible that, elevated homocysteine concentration injures the vascular endothelium in preeclampsia; thereby it contributes to the pathogenesis of preeclampsia. In addition, vascular endothelium in pregnant women may be more sensitive to injury; therefore moderate elevation in homocysteine levels may lead to endothelial injury with subsequent activation of various factors that result eventually in preeclampsia. The great limitation of the study is that multivariate linear regression was not done to adjust the other confounder and odd ratio is not calculated to measure the risk assessmant of hcy level with PE.

\section{Conclusion}

Serum homocysteine was significantly increased in severe $\mathrm{PE}$ and mild PE in comparison to without PE groups. However severe PE and mild PE groups did not differ with respect to serum homocysteine. BMI has got an effect to increase homocysteine especially due to weight of the patients; thus a heavy woman with high BMI is at risk of developing PE. Further cohort or case-control studies with large sample should be carried out to evaluate the association of serum homocysteine with PE.

\section{References}

1. Friedman SA, Taylor RN, Roberts JM. Pathophysiology of Eclampsia. Clin Perinat, 1991;18:661-682

2. Barron WM. The Syndrome of Preeclampsia. Gastro Enterol Clin North Am. 1992;21:851-872

3. Seshadri N, Robinson K. Homocysteine, b Vitamins \& Coronary Artery Disease'. Medical Clinics of North America. 2000;84:215-236

4. Welch GN, Loscalzo J. Homocysteine and atherosclerosis. N Engl J Med .1998;338: 1042-1050

5. Walker MC, Smith GN, Perking SL, Kelly EJ. Changes in Homocysteine Levels during Normal Pregnancy. Am J Obtet Gynecol.1991;180:660-64

6. Vollset SE, Refsum H, Irgens LM, Emblem BM, Tvedral A, Gjessing HK, et al. Plasma Total Homocysteine, Pregnancy Complications, and Adverse Pregnancy Outcomes: the Hordaland Homocysteine Study. Am J Clin Nutr. 2000;71:962-68

7. Zaher A, Majumder AA, Mohibullah AKM, Ali M, Reza AS, Dey A. Homocysteine as a Risk Factor for Coronary Artery Disease in Bangladeshi Population. Bangladesh Heart J. 2003;18(1): 3-5

8. Banu S. Association of Serum Homocysteine in Ischeamic Heart Disease [M Phil Thesis in Biochemistry].2003. Banghabandhu Sheikh Mujib Medical University, Dhaka

9. Wahab MA. Effects of Folic Acid Supplementation on Serum Homocysteine in Coronary Heart Disease Patients. [MD Thesis Clinical Biochemistry]. 2004. Banghabandhu Sheikh Mujib Medical University, Dhaka 10. Boushey CJ, Beresford SA, Omenn GS, Motulsky AG. A Quantitative Assessment of Plasma Homocysteine as a Risk Factor for Vascular Disease. JAMA. 1995; 274:1049-57

11. Cotter AM, Molloy AM, Scott JM, Daly SF. Elevated Plasma Homocysteine in Early Pregnancy: A Risk Factor for the Development of Severe Preeclampsia. Am J Obstet Gynecol. 2001;185;781-5

12. Lopez-Quesada E, Vilaseca MA, Lailla JM. Plasma Total Homocysteine in Uncomplicated Pregnancy and Preeclampsia. Eur J Obstet Gynaecol Reprod Biol; 2003;108:45-49

13. Rajkovic A, Catalano PM, Malinow MR. Elevated Homocysteine Levels with Preeclampsia. Obstet Gynaecol 1997;90:168-171

14. Mignini LE, Latthe PM, Villar J et al. Mapping the Theories of Preeclampsia: The Role of Homocysteine. Obstet Gynaecol 2005; 105:411-25

15. Ingec M, Borekci B, Kadanali S. Elevated Plasma Homocysteine Concentrations in Severe Preeclampsia \& Eclampsia. Tohoku J Exp Med. 2005;206:225-31

16. Agudelo AC, Belizan JM. Risk Factors for Preeclampsia in Large Cohort of Latin American \& Caribbean women. Am J Obstet Gynecol 2000;107(1):75-83 
17. Roberts JM, Cooper DW. Pathogenesis and Genetics of Preeclampsia. Lancet 2001;357; 53-56

18. Stanger O, Herrmann W, Pietrzik K et al. Consensus Paper on the Rational Clinical Use of Homocysteine, Folic acid \& B vitamins in cardiovascular and Thrombotic Diseases': guidelines and
Recommendations. Cardiovascular Forum Online, 2005;0001-0019 19. Winder BC, Enzinger CA, Laich A, Wirleitner BD, Fuchs D. Hyperhomocysteinemia, Pteridines \& Oxidative stress. Current Drug Metabolism, 2002;3;225-232 